\title{
The December 2004-January 2005 floods in the Garden Route region of the Southern Cape, South Africa
}

\author{
Johan Tempelhoff \\ Professor of History, School of Basic Sciences \\ North-West University, Vaal Triangle Campus, South Africa \\ johann.tempelhoff@nwu.ac.za \\ Dewald van Niekerk \\ Director: African Centre for Disaster Studies, \\ North-West University, Potchefstroom Campus, South Africa \\ dewald.vanniekerk@nwu.ac.za \\ Elize van Eeden \\ Professor of History, School of Basic Sciences, \\ North-West University, Vaal Triangle Campus, South Africa \\ elize.vaneeden@nwu.ac.za \\ Ina Gouws \\ Lecturer in Political Science, School of Basic Sciences \\ North-West University, Vaal Triangle Campus, South Africa \\ ina.gouws@nwu.ac.za
}

Karin Botha

Subject Group Tourism Management, School for Business Management North-West University Potchefstroom Campus South Africa karin.botha@nwu.ac.za

Rabson Wurige Post-doctoral fellow Water research group, CuDyWat North-West University, Vaal Triangle Campus, South Africa rabson.wurige@nwu.ac.za

\section{ABSTRACT}

The December 2004-January 2005 floods in the Garden Route region of the Southern Cape in South Africa have had a significant impact on local development and economic activities, tourism products and local institutions. This article aims to capture the dynamism between a number of related fields within the context of transdisciplinary research. Qualitative research methods were used to target a representative sample of the affected population. This article considers the history of the flooding events of December 2004/January 2005 along the Garden Route, as well as the manner in which emergency/disaster management personnel responded to the crisis. The effect of the floods on the tourism sector along the Garden 
Route was researched in general and the effects of the floods on tourists, local residents, and particularly communities in disadvantaged areas were specifically determined. The research reflects on the disaster risk management strategies that were in place at the time of the floods to determine what local authorities could have done to cope with the potential conditions of crisis. The research found that although some tourism products were severely affected, the 2004/2005 floods did not have a significant impact on the number of tourists frequenting the area. In terms of disaster risk management, concerns remain regarding the lack of the following factors: capacity, adequate early warning systems, proper infrastructure maintenance, local institutions, and an in-depth understanding of the disaster risk profile of the area.

\section{KEYWORDS}

floods, Garden Route, tourism

\section{Introduction}

South Africa's Garden Route (the coastal region along the southern Cape coast between Still Bay and the Storms River mouth) is rated among the prime holiday destinations in the country (Leggat \& Klein, 2001:46-51). Annually, thousands of tourists from all parts of the world visit the region for its fascinatingly quaint coastal holiday towns, impressive indigenous forests, mountains and coastal landscapes. Coastal and marine tourism has become a huge business that forms a significant component of the wider tourism industry. It generates more than R15,2 billion annually, with over 20 million international and domestic visitors to South Africa's coastline (Department of Environmental Affairs and Tourism, 1998). For South African holidaymakers, the urban settlements of the Garden Route region are particularly popular destinations during the annual Christmas holidays. The tourism peak season usually extends into January when foreign tourists from the Northern Hemisphere, who have spent Christmas at home, start travelling to South Africa, in order to enjoy local summer weather conditions.

From a weather perspective, the December 2004/January 2005 season was unusual. Many parts of the Western Cape Province experienced the worst drought conditions in more than 25 years (De Beer, 2004:3). Beginning in November 2004, average rainfall figures had been registered in the Garden Route region. Then in December 2004 the pattern changed completely. Along the Garden Route coastal low conditions caused severe rainstorms. Compounded rainfall figures for the major urban centres tell part of the story (South African Weather Services, 2005):

Table 1. Compounded rainfall figures for the major urban centres in the Garden Route (December 2004January 2006).

\begin{tabular}{|l|l|l|}
\hline \multicolumn{1}{|c|}{ Town } & \multicolumn{2}{c|}{ Accumulated rainfall record (mm) } \\
\hline & DECEMBER 2004 & JANUARY 2005 \\
\hline Mossel Bay & 120.5 & 26.0 \\
\hline George & 143.7 & 80.5 \\
\hline Knysna & 423.0 & 64.6 \\
\hline Plettenberg Bay & 162.6 & 54.8 \\
\hline
\end{tabular}


The rainstorms and consequent floods, which caused significant damage in many areas, were not declared a disaster, yet the events commanded wide coverage in the news media. This omission to declare a provincial disaster was mainly due to two factors. Firstly, the Disaster Management Act 57 of 2002 states that a disaster is a provincial disaster only if the event affects more than one district municipality, or if one district area with the assistance of its local municipalities are unable to cope using their own resources. With the December 2004/January 2005 floods only one district (Eden District Municipality) was severely affected. One could argue that the district municipality and all its local municipalities were unable to cope, thus the situation warranted a provincial declaration or at least a local state of disaster declaration. The second reason for not declaring this event as a disaster was politically motivated. There was a perception in Government, that the declaration of a state of disaster would negatively reflect on the management capacity of the Western Cape Province and also that such a declaration might have a profound impact on the tourism industry in this particular area. Early estimates in Western Cape government circles suggested that it would cost at least R25 million to recover from this event (2004:2, 2004:1). In the Garden Route region specifically, one insurance firm confidentially disclosed that a total of 1224 claims had been processed. The company had to pay out an estimated R20,4 million (Van Niekerk, 2005).

The objective of this research project was to consider the cultural dynamics, i.e. the human response to nature under extraordinary climatic conditions. Interviews were conducted with officials $(n=31)$, local residents and members of the tourism industry $(n=16)$ who had been directly affected by the events of December 2004/January 2005. The respondent sample of the officials represented all of the senior disaster management officials at local, district and provincial level, as well as a number of related departments. All of the members of the tourism industry sustained direct losses due to the event. The sample is a fair distribution and is representative of the general population. Source material was also consulted in newspapers and official documents. The fact that the investigation was conducted in March-April 2005 made it possible for the researchers to trace events at a time when the immediate memories of the events had started fading and had shifted into a phase of reflexive recollection of what had transpired. The objective of the research team was to consider the history of the floods from a transdisciplinary perspective. Through frequent interaction members exchanged ideas and theories.

The following themes were identified for investigation:

1. The history of the flooding events of December 2004/January 2005 along the Garden Route;

2. The manner in which emergency/disaster management personnel responded to the crisis;

3. The effect of the floods on the tourism sector along the Garden Route; and

4. The effect of the floods on tourists, local residents, and particularly communities in disadvantaged areas;

In the discussion below attention will be given to these and other related issues.

\section{Historical overview}

Historically the Garden Route region may be considered a prime habitat for human settlement. There is abundant evidence of early San and Khoikhoi settlements in the region dating 
back several centuries (Van der Merwe, 2002:22). Iron Age agro-pastoralists came from the north-east in the eighteenth century. The first European presence in the region dates back to the fifteenth century when Portuguese mariners set foot on the shores of the Garden Route(Sleigh, 2004:6). However, it was only after the establishment of a Dutch settlement at the Cape that hunters and travellers started frequenting the region. The demand for timber supplies for consumption at the Cape (Stals, 1961:74-82) led to permanent settlers in the region (Van der Merwe, 2002:28). The local farming industry, as was the case elsewhere on the frontiers of the Cape (Guelke and Shell, 1992:816) initially centred on livestock farming, (Sparrman, 1975:217), but soon cropping activities also increased substantially. Hunting (Mackay, 1996:27) and trading activities (Parkes \& Williams, 2004:3-5), brief spurts of mining activity (Anon, s.a.), the emergence of cottage industries such as furniture manufacture (Stals, 1961:99) and boatbuilding (Bischoff, 2004:79-81) - all related to carpentry - provided the necessary impetus for community development.

\section{Fig 1. Eden District Muncipaity}

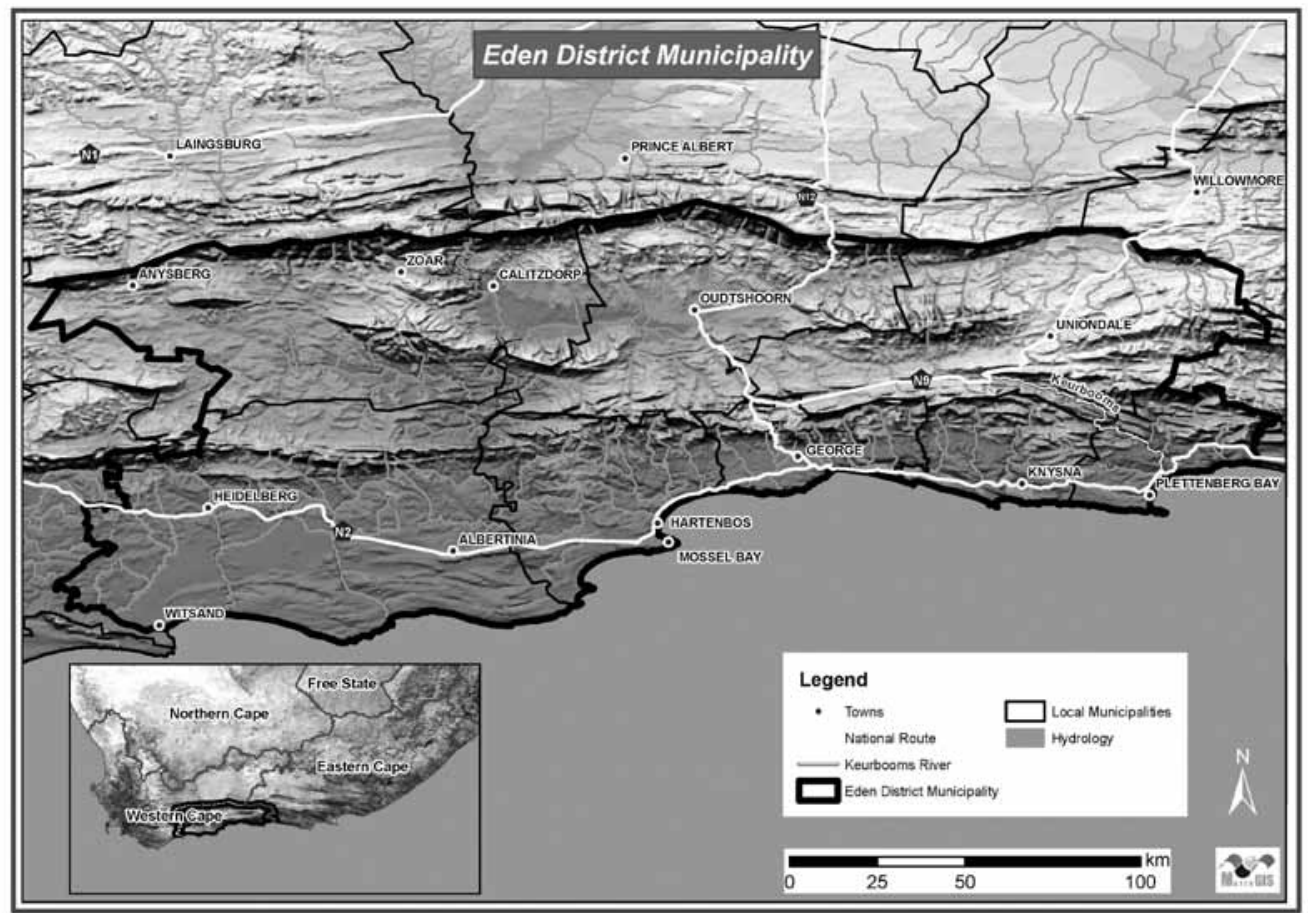

Source: MetroGIS (Pty) Ltd

In the latter part of the twentieth century the development of the PetroSA project (formerly Mossgas), for mining the gas deposits off the coast of Mossel Bay in the Indian Ocean (PetroSA, 2006), provided a significant boost to industrial development in the region. Up to the present, the local chemical and related industries provide the most intensive industrial activity in the region.

Trade and commerce flourish in the urban centres of the region. Mossel Bay, the oldest urban settlement in the region, was founded as a village in 1848 (Sleigh, 2004:614-616). 
It became a municipality in 1852 (Raper, 2004:252). George was the first town to be proclaimed (1811) after the British had annexed the Cape Colony in 1806 (Raper, 2004: 111). Knysna, a name derived from the Khoikhoi language (meaning ferns or fern leaves), became a local authority in 1881 after the two hamlets of Melville (founded 1825) and Newhaven (founded 1846) were consolidated to form the new town (Raper, 2004:180). Plettenberg Bay, the youngest of the coastal towns, became a municipality in 1961. It is named after a former Dutch East India Company governor, Joachim van Plettenberg (1739-1793) (Raper, 2004:308).

Tourism, informal and permanent, remains one of the pillars of the region's economy. Since the nineteenth century, particularly after the development of the lucrative ostrich industry, wealthy farmers increasingly began to invest locally in holiday homes that were ultimately destined to become places of retirement. South Africans resident in other parts of the country, with similar objectives in mind, also started settling in the region.

\section{Fig 2. Garden Route Map}

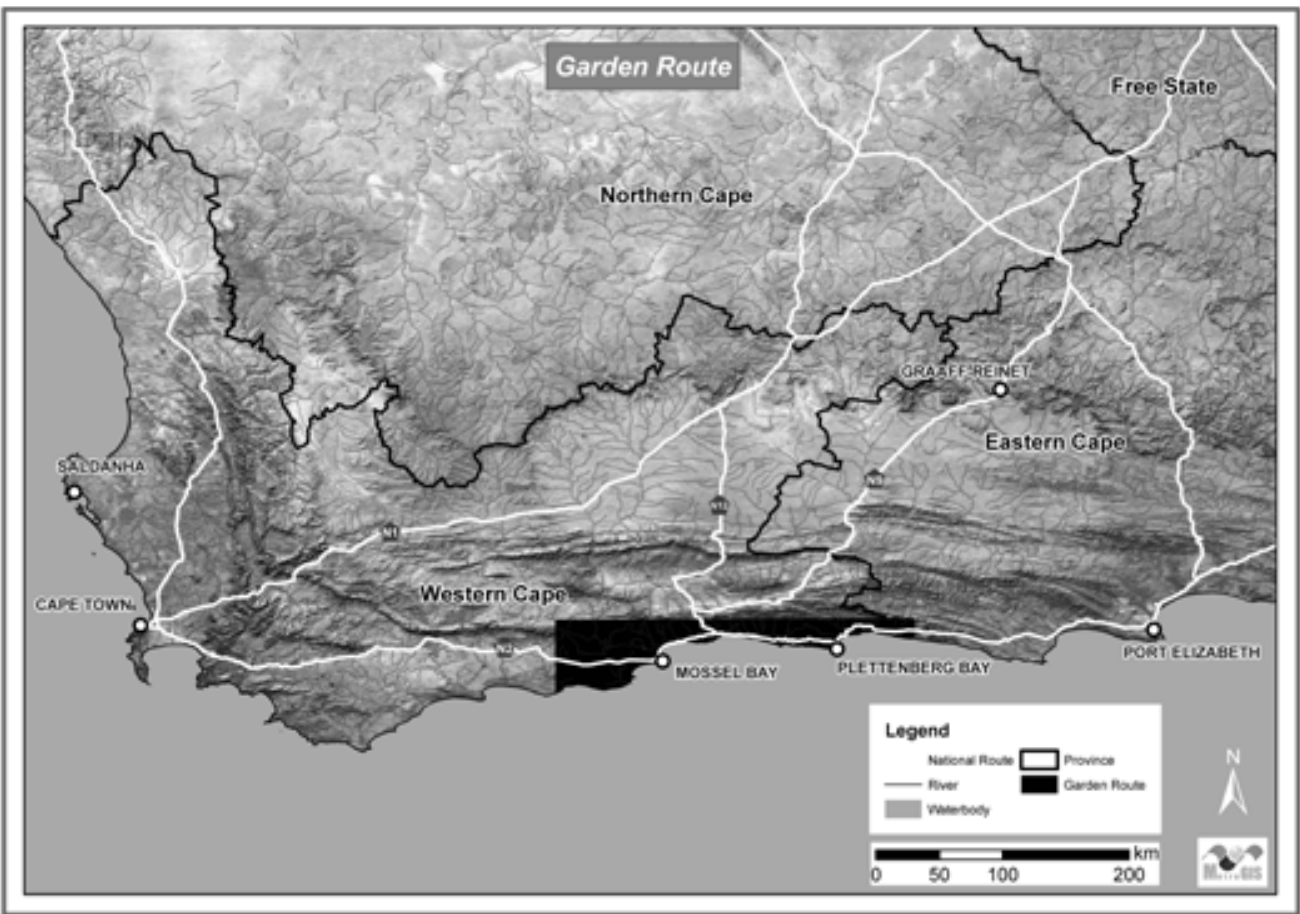

Source: MetroGIS (Pty) Ltd

In the twentieth century, with the growth in international travel, the Garden Route region became a popular tourist destination. During the Christmas holidays the Garden Route is a prime destination for South African holidaymakers. In the absence of reliable current figures, population data from the national census of 2001 for the major urban centres along the Garden Route were used (Table 2). According to officials at the local municipalities, the population in the areas under their jurisdiction has increased by as much as six times from those shown in Table 2 . This is a conservative estimate. A total resident population of between 2 and 2,5 million people in the region over the Christmas holidays would be a more realistic estimate. Clearly, such a rapid increase in population would stretch the available potable water supplies 
Table 2. Estimated December population figures in the major urban centres along the Garden Route

\begin{tabular}{|l|r|r|}
\hline \multicolumn{1}{|c|}{ Urban centre } & Census 2001 & \multicolumn{2}{c|}{$\begin{array}{c}\text { Estimated population } \\
\text { December peak season }\end{array}$} \\
\hline Mossel Bay & 71439 & 428634 \\
\hline George & 135409 & 812454 \\
\hline Knysna & 51468 & 308808 \\
\hline Plettenberg Bay & 6681 & 40086 \\
\hline Total & $\mathbf{2 6 4 9 9 7}$ & $\mathbf{1 5 8 9} \mathbf{9 8 2}$ \\
\hline
\end{tabular}

Source: Statistics SA, 2005

in the region. From the interviews conducted during fieldwork, it merged that the impact of this rapid population growth manifested in a diversity of trends. Another factor is the significant growth in new housing projects in the region (Anon, 2004:27; 2004:1; .2005:1). Many South Africans have, in the past decade, started relocating to the region to settle after retirement. This trend has increased since 2000.

\section{Climatic history}

Extreme weather conditions in all parts of the world can be ascribed to global warming and varying climatic patterns (IISD, 2005). Particularly at a time when progressively more questions are being asked relating to a presumed increase in the number of natural disasters (Williams, 2005), it is a subject, in the opinion of the researchers, that deserves to be investigated and monitored carefully in future. Historical records show that floods have frequently occurred in the region. Floods have wrought havoc in areas of the Garden Route where human settlement and development are found. Flooding events of significant proportions have been recorded for the years $1847,1867,1875,1905,1910,1916,1929,1931,1932,1940,1954,1961,1967$, 1977, 1981, 1998 and 2003 (Du Plessis, 1984;Malan, 1970:12; Anon. 1977; The Mossel Bay Advertiser, 1905; Fourie, 1998; Meyer, 1999; Sayers, 1982:20).

\section{The effect of the floods on the tourism industry}

Tourism is the single largest industry in the world and has become a significant contributing sector of the global economy (South Africa, 1998). South Africa is a flourishing tourist destination and the South African Tourism Board (SATOUR) recorded a steady growth in international visitors of about 11\% per annum over the past decade (Leggat \& Klein, 2001:46-51). Surveys show that the Garden Route is among the top four holiday destinations in the country (Leggat \& Klein, 2001:46-51). Accordingly, natural disasters such as those experienced along the Southern Cape coast in December 2004/January 2005 could have serious impacts on the local tourist industry.

Globally, tourism is frequently beset by natural and human disasters that devastate the industry in a particular area (Beaman, Haun \& Shelby, 2003:255). Of particular concern is the fact that tourism management capability and ability to deal with complex and critical situations are limited (Santana, 2003:299). Despite the need for research on tourism and natural disasters, 
only limited progress has been made in the analysis of the impacts of disasters on tourism. It is also abundantly clear that the industry seldom plans adequately for disaster occurrences. Crisis management plans are sometimes only developed in response to a particular disaster and development occurs with varying degrees of speed and effort (Faulkner \& Vikulov, 2001:331$344)$.

The damage to tourism caused by the December 2004/January 2005 floods in the Southern Cape was primarily economic. It specifically affected the accommodation sector of the industry. From a holistic point of view, the negative effects of the floods were fourfold, namely: the psychological impact; structural damages to product facilities; damage to infrastructure and water pollution; as well as to the safety and protection of tourists.

Without adequate contingency plans, tourism products of the public and private sectors can compromise the safety of tourists. Research fieldwork showed that Hartenbos and the residential area surrounding the Protea Hotel on the Keurbooms River had no effective stormwater systems (Liebenberg, 2005). The lack of this apparently insignificant infrastructural element can jeopardise sustainable tourism in the Southern Cape and nationally. Owing to the December 2004/January 2005 floods the operation of the Outeniqua Choo-Tjoe, a popular tourist train along the Garden Route, was suspended, causing a loss of an estimated R700 000 in revenue (2005:4; 2005:1).

A review of the tourism accommodation facilities and products in the study area that suffered severe damage shows that few had adequate, thorough and clear evacuation plans or emergency drills in place. The plans of the product operator should, for instance, state the gathering points in times of emergency, have a prioritised list of actions indicating what employees should do during a crisis, and indicate where all the main electricity points can be manually turned off.

Research conducted by Engelbrecht and Engelbrecht (in Schulze, 2005) on the regional projections relating to rainfall utilising the Conformal-Cubic Atmospheric Model (CCAM) model, indicates that the southern Cape area can expect to become drier. This is due to a projected southerly movement of cold fronts which brings winter rains to the south and south-western Cape. This southerly movement might be caused in the future by the strengthening of subtropical high-pressure belts over South Africa in the winter (Engelbrecht, McGregor \& Engelbrecht, 2008). In essence this projection of a changing climate along the Garden Route might make the area even more favourable as a tourist destination.

\section{Floods and informal settlements}

Since the second half of the 1980s South Africa's urban landscape has been noted for the prevalence of informal settlements on the periphery of the country's towns and cities. This trend is a consequence of increased urbanisation as observed on a global scale for the greater part the twentieth century. However, informal settlements are also the result of the relaxation of control measures by the former apartheid government in the 1980s and subsequently, in 1991, the official scrapping of influx control measures. 
After the first democratic multi-racial elections of 1994, the flow of people into the urban environment took place at a considerably faster rate as a result of the greater degree of personal freedom of movement. This influx of people into the urban areas is an outstanding feature of the demographic profile of the country. The settlement of people in these areas was further exacerbated by the farming sector cutting back on labour requirements, in the face of Government's insistence on equitable remuneration and participatory practices. However, with the exception of the Mossel Bay region, where job opportunities have been readily available due to the development of Mossgas (now PetroSA) since the 1980s, the growth of informal settlements in the Garden Route region was minimal. In comparison with the highly industrialised regions of Gauteng, KwaZulu Natal, the Eastern Cape and the Cape Peninsula, the growth of these settlements has not been exceptional.

Conducted fieldwork determined that in the informal settlements, the December 2004-January 2005 holiday season did not imply a significant growth in population. In fact, there were indications of a population decline. In the holiday season many residents of squatter camps tend to visit 'home', the rural areas of the Eastern Cape, Lesotho, KwaZulu-Natal, the Free State and Mpumalanga. With residents away from home, houses in informal settlements are exposed to significant damage. Squatters' shacks are typically not sturdy and do not offer secure shelter in the event of extreme weather conditions.

The streets of these informal settlements are particularly prone to damage. They are generally not intended for permanent use. The land on which the settlements have been laid out is generally on a high elevation and is noted for the steep hills and inclines down which storm water easily flows along natural valleys and gullies. Information gleaned from interviews suggests that the lack of proper road drainage systems and the lack of proper housing are crucial problems. Respondents repeatedly charged the Government with not meeting the needs of the people. It was argued that the Government was not fulfilling its moral obligation to make opportunities available for the disadvantaged. There was distinct evidence of a communication gap between the expectations of the citizens and the goals of the responsible local authorities.

\section{Disaster risk management}

\section{Disaster risk management legislative requirements}

The Constitution of the Republic of South Africa (Act 108 of 1996) places a legal obligation on the Government of South Africa to ensure the health (personal and environmental) and safety of its citizens. In terms of section 41(1)(b) of the Constitution, all spheres of Government are required to "secure the well-being of the people of the Republic". Section 152(1)(d) also requires that local government "ensure a safe and healthy environment". Accordingly, the primary responsibility for effective disaster management in South Africa rests with Government.

The most important government sphere for the effective implementation of disaster management is local government. Local government is where most of the operational activities (risk reduction as well as response) relating to disaster management will occur (South Africa, 1999:80). The local sphere of government must therefore ensure that the functional strategies, 
policies, programmes and projects find embodiment at community level. This should be done through the development and implementation of standing plans, local policies, procedures and rules, such as disaster management plans and Integrated Development Plans (IDPs). The IDP is the functional plan through which municipalities ought to operationalise all services and public goods. The IDP also serves as the operational plan for development and disaster risk reduction in any municipality. The local disaster management plan must be integrated within the IDP. Such integration should ensure that disaster risk is addressed through development initiatives and that a municipality does not engage in high-risk development or developments which might increase community vulnerability.

The Disaster Management Act is very specific when it comes to institutional capacity requirements within the local sphere of government. Each metropolitan and district municipality must establish a disaster management centre within its area of jurisdiction. Community and consultative participation is ensured through the establishment of a Disaster Management Advisory Forum (DMAF) ${ }^{\mathrm{II}}$ and disaster management volunteer structures. The requirements of the Disaster Management Act were to be adhered to by all municipalities by 1 July 2006. Of paramount importance in the implementation of disaster risk management measures is their incorporation in development planning.

\section{Disaster risk management and development planning}

Disaster risk management in South Africa consists of a labyrinth of cross-cutting facets requiring the participation of a host of sectors and disciplines not only from within the spheres of Government and different government departments, but involving the private sector, civil society, non-governmental organisations (NGOs), community based organisations (CBOs), research institutions, and institutions of higher learning, to name but a few (Van Niekerk, 2004). Therefore, disaster risk management involves a wide array of different role-players and professional constituencies (Jeggle in Rosenthal, Comfort \& Boin, 2001). In order for disaster risk management to be successful, knowledge and mechanisms have to be based on solid scientific precepts (Gunn, 1992:17).

Jeggle points out that there are distinctive managerial and functional implications for the organisation of risk and disaster management for the future (Rosenthal et al, 2001:335). The White Paper on Disaster Management (South Africa, 1998), clearly spells out that one of the key policy proposals is the "urgent integration of risk reduction strategies into development initiatives" (Van Niekerk, 2001). For this purpose, Government has enforced the integration of disaster management planning into all developmental planning within all spheres of Government, but at local level in particular (South Africa, 1998). Experience in the international as well as local arena has shown that activities relating to disaster risk management cannot function separately from the broader Government context (South Africa, 1998). It has been observed that isolated planning by numerous Government institutions and functions leads to duplication and waste of valuable public resources (DPLG, 2001).

\section{Disaster risk management in the Eden District and local municipalities}

Although the Disaster Management Act was promulgated on 15 January 2003, its operationalisation within provinces and municipalities only occurred from 1 April 2004 and 1 July 
2004, respectively. Therefore each of these spheres of Government had a two-year period in which to comply with the basic requirements of the Disaster Management Act.

In compliance with the Disaster Management Act, the Eden District Municipality (EDM) was in the process of establishing their disaster risk management structures at the time of the flood of 2004-5. A district Disaster Management Advisory Forum (DMAF) had been established and was functional (Van Niekerk, 2005). This forum was, however, still undergoing some structural changes to cater for the risk profile of the EDM, and to align it with the DMAF of the Western Cape Province. Furthermore, the EDM was also assisting local municipalities in the development of their disaster management plans. The EDM also allocated new office space for the district Disaster Management Centre, which was intended to ensure a dedicated centre before the end of 2005 (Van Niekerk, 2005).

Although the Disaster Management Act does not enforce disaster management institutional capacity at local municipal level, all the local municipalities within the EDM had a focal point for disaster management related issues. In all the local municipalities the incumbent responsible for disaster management was also already responsible for another function of Government (e.g. the Fire Chiefs in both Knysna and George Local Municipality were also responsible for the disaster management function and in the case of the Bitou Local Municipality, the Traffic Chief had to attend to this function, while in the case of the EDM two people had been appointed to the Disaster Management Centre, but the manager of the disaster management function also had to manage the district management area) (Van Niekerk, 2005). Research suggests that the allocation of the disaster management function to an already existing and in most cases overburdened government functionary leads to the inadequate management of disaster risk (University of Cape Town, 2003: 114-119). This also contradicts section 45 of the Disaster Management Act which gives specific guidelines as to the appointment of the head of a district disaster management centre. The lack of a dedicated focal point in all local municipalities is of concern. From the research, it became apparent that although disaster risk was being addressed through a multi-disciplinary approach within the district and local municipalities, there were no clear coordinating structures at local municipal level (Knoetzen, 2005).

The lack of clear disaster risk management guidelines and procedures from National Government has in many instances caused an implementation bottleneck at local government level. This is evident in the Eden District Municipality. Many municipalities have not received guidelines on the exact requirements of the disaster management plan and related disaster risk assessment (Swiegers, 2005; Nelson 2005; Otto, 2005; Pretorius; 2005). In the absence of national guidance, the Western Cape Provincial Disaster Management Centre has provided its own guidelines for the compilation of these disaster management plans (Carstens, 2005). The application of these guidelines at local municipality level is still limited (Swiegers, 2005; Nelson 2005; Pretorius; 2005).

In the research conducted it became evident that each municipality tended to address issues of disaster risk management differently. In the case of the George Local Municipality, disaster [risk] management was seen as an overarching function in which every line function had a 
responsibility (Nelson, 2005). The extent to which the coordination of all the disaster risk management activities was occurring could not be clearly established. In the case of the Knysna Local Municipality, the Fire Chief in cooperation with other Government entities (e.g. South African National Parks (SANParks) and the town engineer) tended to consult and coordinate their actions (Pretorius, 2005; Joubert, 2005; Langlands, 2005). Although a top management structure of politicians and municipality officials (e.g. the municipal manager, executive mayor, politicians and departmental heads) did exist in the Knysna and Bitou Local Municipalities, the lines of communication were not clear and in many instances decisions were being made in isolation (Joubert, 2005; Pretorius, 2005; Swiegers, 2005).

\section{Institutional development and support for disaster risk management}

It is clear that the water management infrastructure was a problem in all the municipalities. It became apparent that local municipal budgets only allowed for maintenance and not for expansion of infrastructure to effectively cope with flood situations (Liebenberg, 2005). In the case of floods the main aim of the management of water infrastructure was to deal with the large amount of water flow during heavy rainfall. Effective storm water drain systems or channels would be the best way to deal with this problem. However, the prevailing systems in these municipalities were not effective, especially in lower-income areas which experienced severe damage. For example, the town of Hartenbos, which did not have a storm drain system, suffered severe damage (Liebenberg, 2005). The research showed that there was no effective maintenance plan. Mr Swanepoel of SANParks in Knysna remarked that a lot of experienced technicians had retired, taking with them years of expertise and institutional memory (Joubert, 2005). Due to budget limitations the experienced technicians had developed their own ways of maintaining the water infrastructure. Following their retirement, new technicians were appointed who had been trained in more modern technology, much of which had not yet been installed by most municipalities. Thus, in effect, their technical knowledge proved to be of no use under the prevailing circumstances.

The Municipality of George did not suffer heavy damage during the floods (Swanepoel, 2005). There were enough rivers and channels in and around the town to direct the storm water away from residential areas during heavy rains. However, there were blockages in storm drains in certain areas and the infrastructure in townships was sub-standard. Clearly, therefore, the necessary infrastructural service system was not in place.

In Bitou Local Municipality, similar water infrastructure challenges were experienced. A further problem that was identified was the issue of vast distances when it came to maintenance of infrastructure (Geldenhuys, 2005). Maintenance support had to be called up from BeaufortWest, 200 kilometres away.

Regarding implementation of the social strategy in times of disaster at the municipal level, only one of the interviewees believed that the heavy rains and the subsequent floods could have been predicted (Geldenhuys, 2005). As a result, no real preparations were made to try to prevent 
actual flooding or damage due to floods. It was pointed out that, in general, the issue of floods did not stay on the agenda for too long in municipalities (Liebenberg, 2005). When the initial shock and scare wore off, priorities shifted to other areas of management resulting in the provision of infrastructure to deal with floods receiving low priority.

During fieldwork, researchers noted that local water restrictions were in effect. Restrictions only affected the use of water for gardening, not domestic use. In Knysna the problem did not seem to be a shortage of potable water, but rather the non-maintenance of infrastructure (Joubert, 2005). Water pipes leaked for days without being attended to.

Another issue that was identified was development, and specifically the areas in which development was taking place. Municipal officials stated that they could not prohibit developers from building below flood lines. Some stated that there were no laws prohibiting this, and that their only responsibility was to warn town developers about river flood lines. Indications are that provincial and local authorities were reluctant to engage developers on the matter (Swanepoel, 2005). The only municipal official to state otherwise was the spokesperson for George $\mathrm{Mu}-$ nicipality who noted that the municipality absolutely prohibited any development below the flood line (Swanepoel, 2005). This raised some concern with the researchers, given that the necessary measures exist in the framework of the National Water Act. In addition, indications were that flood lines were not properly mapped in the respective municipalities. Furthermore, developers generally do not plan developments according to the climate, demographics and rainfall characteristics of a specific area. Seemingly they adhere only to national standards of development, which do not always take area specific conditions into account.

This background study was necessary for the better understanding of the management of the floods of December 2004/January 2005. The following section will focus on the aspects specifically related to the management of the December 2004/January 2005 floods.

\section{Disaster risk management of the floods of December 2004/January 2005}

The research conducted in the Eden District established that all local municipalities agreed that floods of this nature could have been foreseen due to the historical occurrence of floods at that time of the year. All respondents indicated that although a risk perception of flooding did exist, clear guidelines for action were lacking. The exact response of municipalities to different warnings was still problematic (Pretorius, 2005; Joubert, 2005; Otto, 2005). In most instances municipalities tried to avoid a "cry wolf" situation (Nelson, 2005) and would instead wait to see what happened before a reaction was sanctioned (Swiegers, 2005).

Effective and timely early warning is the foundation of effective disaster response and risk reduction (Paulsen, 2004). In the case of the December 2004/January 2005 floods early warning was provided by the Western Cape Weather Service office, the provincial Disaster Management Centre and the EDM (Van Niekerk, 2005). Nelson (2005) indicated that two warnings were received for the period under investigation. The George Local Municipality did not, however, react to these warnings because the municipality did not foresee severe flooding. 
According to one of the respondents, the Knysna Local Municipality only received a warning for the second floods (January 2005) (Van Niekerk, 2005). Reaction to these floods by the Knysna Municipality was minimal due to the fact that inadequate guidelines exist for the response to warnings. In another interview, the respondent pointed out that the Bitou Local Municipality did not receive any forewarning of the floods. Although a risk perception did exist in the Bitou Local Municipality, the reaction to the floods was slow because they "were not sure what would happen after the heavy rains" (Swiegers, 2005). Evidently, although a system to communicate early warnings to the different municipalities exists, the communication of the warning to the possibly affected communities seldom occurs adequately.

As argued above, the legal requirement for the integration of a disaster management plan into the integrated development plan of each municipality is of paramount importance. A review of the IDPs of the municipalities under investigation shows there was limited integration in some of the municipalities (Otto, 2005) and in others it still had to happen (George Municipality, 2002:62). Such integration is imperative in order to ensure that all organs of state engage in disaster risk reduction activities as part of their daily operations. In this way aspects which could contribute to an increase in disaster risk can be addressed. For instance, the lack of adequate maintenance of infrastructure which led to blocked storm water drains and water channels, as well as weak and outdated infrastructure, exacerbated water runoff and increased flooding during the December 2004/January 2005 floods (Otto, 2005; Pretorius, 2005; Swiegers, 2005). This has been noted as a major contributing factor to the floods.

The research conducted revealed that most of the municipalities affected by the floods did have some form of contingency plan in place (Nelson, 2005; Pretorius, 2005). Spokespersons of the Bitou Municipality indicated that they did not have a specific plan for flooding because they had limited capacity in the municipality to "draw up such plans" (Swiegers, 2005). The response to the floods was in accordance with a generic contingency plan. It was indicated that although they did implement some aspects of the plan, it needed urgent revision (Pretorius, 2005). George Municipality's generic contingency plan was still based solely on an outdated disaster profile and did not make adequate provision for the new requirements of the Disaster Management Act (Nelson, 2005). A respondent of the Eden District Municipality suggested that cognisance should be taken of the fact that disaster management in South Africa was still in a developmental phase. It was pointed out:

The flood occurrences allow us to learn and better our planning (Otto, 2005).

In terms of multi-roleplayer involvement, all respondents indicated that a good and coordinated approach with all other departments in the Eden District Municipality was ensured. In most instances other municipal departments took responsibility for their specific functions, thereby ensuring a multi-roleplayer response to the floods (Nelson, 2005; Pretorius, 2005; Swiegers, 2005).

Following the floods, each municipal department did its own impact assessment. The overall assessment of the flooding was coordinated by the Western Cape Provincial Disaster Manage- 
ment Centre (Western Cape Provincial Disaster Management Centre, 2005). Research indicated that no uniform standards for conducting disaster assessments were present in the Eden District Municipality (Otto, 2005). The lack of such standards evidently created a predicament when it came to the declaration of a local state of disaster or the declaration of a disaster.

Adequate assessment guidelines would have enabled responsible officials at the Eden District Municipality to determine when an event should be declared a disaster (Otto, 2005).

\section{Disaster risk management lessons learnt from the December 2004/January 2005 floods}

The 2004/2005 floods provided certain lessons for disaster risk management. Some of which include:

- There is an urgent need for a thorough and proper disaster risk assessment (for all hazards and vulnerable communities) for the whole of the Eden district.

- Guidance and guidelines must be provided to the local municipality on the development of disaster management plans, disaster assessment and the declaration of a local state of disaster.

- A more effective early warning system will facilitate an easier and adequate response to floods.

- All response and risk reduction activities should be done through clearly defined and coordinated multi-stakeholder involvement.

- All knock-on effects of floods should be considered prior to an event.

- Maintenance of existing infrastructure is of paramount importance and will significantly lessen the impact of floods in urban areas.

- "What-if" scenarios should be discussed in terms of the risk which the municipality faces.

- Planners of new infrastructure developments should consider the risk increasing potential of all new forms of infrastructure and consider "what-if" scenarios as part of their planning and implementation of developments.

- Existing infrastructure should be mapped (through a Geographic Information System) and this information must be made available to all role-players.

- Emergency water provision should be part of contingency planning and should be in place before floods occur and not only be planned once floods occur.

- Redevelopment should result in infrastructure that is robust enough to resist future floods of the same magnitude (Nelson, 2005; Pretorius, 2005; Joubert, 2005; Langlands, 2005; Swiegers, 2005).

Political buy-in and understanding of disaster risk management remains an immense challenge within the South African local government environment. The lack of such understanding leads to inadequate and delayed decision-making. Politics drives the risk process. Political decisions 
are based on tangible development outcomes which will ensure a favourable view of the politicians in the eyes of the electorate. It remains a huge challenge for politicians to channel public money away from physical developmental projects to intangible risk reduction projects. A balance must be reached between new infrastructure developments and the maintenance of existing infrastructure.

A review of the early warning system of the Western Cape Province as well as the EDM reveals four challenges:

- Firstly, the communication channels used for early warning remain inadequate (mostly faxes and SMSs are used with little direct contact between role-players). Consequently, some municipalities received all the warnings and others did not.

- Secondly, no clear guidelines existed on appropriate response once a warning is issued. Early warning thresholds need to be decided upon and the action needed once a threshold is reached must be clear.

- Thirdly, the existing channels for the communication of warning to communities were inadequate. Whereas the Bitou Local Municipality used a loudspeaker system within communities to warn them of approaching conditions (Swiegers, 2005), the Knysna and George Local Municipalities did not have such a communication channel in place (Pretorius, 2005; Joubert, 2005; Nelson, 2005).

- Finally, community awareness campaigns should be implemented in order to heighten the risk perception of at-risk communities, and in doing so, also instil risk-avoiding behaviour. Such awareness campaigns will provide the communities with adequate knowledge as to the appropriate response once a warning is issued.

One of the most critical aspects which must be addressed within a local municipality is multisectoral and multi-roleplayer involvement in the disaster risk management process. All government functions have to be sensitised on their role in reduction and management of disaster risk. A number of government departments have bought into the principles of disaster risk management and are applying these principles within their areas of responsibility.

The fact that the December 2004/January 2005 floods were not declared a disaster does not necessarily point to good management at district or local government level. A disaster is defined by the Disaster Management Act as a human-made or natural occurrence which significantly impacts on the normal functioning of a community to such a degree that the community (e.g. local municipality) in question cannot cope by using only their own resources. External intervention is therefore required. The research shows that adequate coping capacity existed in most instances. This can be ascribed to the geographic impact of the floods. Most of the flooding occurred due to weak and ill-maintained infrastructure in the urban areas (mostly affluent areas). Most of the losses were insured and therefore did not have a significant impact on the coping capacity of the respective municipalities (Anon, 2005). It should, however, be noted that had the bulk of the flooding occurred in poorer and more vulnerable communities a totally 
different situation would have unfolded. Evidently, the ability of the municipalities to cope, using only their own resources, would have been exceeded, leading to the declaration of a disaster.

\section{Conclusion}

Historically, the Southern Cape region has been conducive to human settlement. Traces of ancient places of residence occur in various parts of the coast. As a result of its natural splendour, the Garden Route remains one of the most scenic parts of South Africa. It is also apparent that the landscape is rapidly changing as physical infrastructure development continues to take place at a remarkable rate. The presence of humans, particularly since the beginning of the twentieth century, has subjected the diverse natural landscapes to change. Cultural activities, initially with hunting, farming, extensive forestry activities, and later in the form of trade, commerce and comprehensive industrial activities have changed the landscape significantly. It is as a result of these human interventions that the extraordinary floods of 2004-2005 registered so markedly on the physical landscape. Had the region been less densely populated the floods might have been recorded as simply one among many other natural events.

From the perspective of the tourist industry, it appears as if the floods could have had a negative impact on tourism in the region. However, the Southern Cape is still one of the premier tourist destinations in South Africa. It is unlikely that the floods of 2004-2005 would act as a significant factor in curtailing tourist arrivals to the region, given the predictions of climate change models.

In terms of disaster risk management, it was evident that all the structures, outlined in terms of legislation, had not yet been implemented. It was also evident that increased integration is required between the central, provincial and local systems of governance. Among the most important lessons for disaster risk management from the 2004/2005 floods is an urgent need for a thorough, district-wide disaster risk assessment. More effective early warning systems and public awareness channels are required to enable appropriate responses to future floods. All response and risk reduction activities should be clearly defined and coordinated, with multistakeholder involvement. Maintenance of existing infrastructure is of paramount importance and will significantly lessen the impact of floods in the urban areas. The lack of proper road drainage systems and housing should be addressed as a matter of urgency. The need for dedicated disaster risk management focal points in all local municipalities must be stressed. Without such focal points, concrete disaster risk management activities will remain a misapprehension. 


\section{References}

ANON. Company profile at website of the Central Energy Fund, PetroSa (Pty) Ltd [WEB:] http:// www.cef.org.za/group/PetroSA/. [Date of access:] 5 March 2005.

ANON. 1905. "The water supply interrupted". The Mossel Bay Advertiser: 1,11 Apr.

ANON. 1977. R100 000 ketch runs aground”. Het Suidwestern: 1, 6 Jun. Information Photo files Mossel Bay Museum;

ANON. s.a. . Millwood Goldfield Society: the story 1875-1891. Millwood Goldfield Society: Knysna Stationers.

ANON. 2004. "Resort planned on Dwarsberg farm”. George Herhald/Het Suidwestern: 27, 24 Jun.

ANON. 2004. "About-face from local property market". Southern Cape Property Guide: 1, 25 Jun.

ANON. 2005. "Huge development on the Swartvlei shore: a final chance to comment". George Herhald/Het Suidwestern: 1, 17 Feb.

BASSON, H. \& SWART, M. 2005. Interview with author. George.

BEAMAN, J., HUAN, T. \& SHELBY, L. J. 2003. No-escape natural disaster: mitigating impacts on tourism. University of Wisconsin. 31: 255

BISCHOFF, L. 2004. The Sedgefield Saga. Private publication. Knysna Press. pp. 79-81.

CARSTENS, S. 2005. Interview with author (Telephonic). Cape Town.

COMPION, J. (Chief Health, Eden District Municipality)/E.S. van Eeden, 8 April 2005

DE BEER, A. 2004. Water restrictions. George Herald/Het Suidwestern: 3, 2 Dec.

DEPARTMENT OF ENVIRONMENTAL AFFAIRS AND TOURISM. 1998. Coastal Policy Green Paper: towards sustainable coastal development in South Africa.

DEPARTMENT OF PROVINCIAL AND LOCAL GOVERNMENT (DPLG). 2001. IDP Guide Pack - General Overview. Pretoria: Government Printer

DEPARTMENT OF WATER AFFAIRS AND FORESTRY. 2004. Internal strategic perspective: Gouritz Water Management Area. Tafelberg Publishers. 2ed. p22

DISASTER MITIGATION FOR SUSTAINABLE LIVELIHOODS PROGRAMME (DiMP). 2003. March 2003 Cut-off Low: (Consolidated Report. Department of Social Services and Poverty Alleviation of the Provincial Government of the Western Cape. Cape Town: University of Cape Town. pp. 114-119).

DU PLESSIS, D. B. 1984. Documentation of the March-May 1981 floods in the South Eastern Cape, (Technical report TR120 of the division of hydrology, Department of Water Affairs, Pretoria).

EDITORIAL COMMENT, The Mossel Bay Advertiser, 1905.09.19.

ENGELBRECHT, F.A., MCGREGOR, J.L. \& ENGELBRECHT, C.J. 2008. Dynamics of the Conformal-cubic atmospheric model projected climate-change signal over southern Africa. Int. J. Climatol. DOI:10.1002/joc.1742.

ESSOP, P. 2004. Flood damage bill R25m and counting. The Cape Argus. Des. p. 2; Van GASS, C. 2004. Cape floods claims 'run into millions. Business Day. Des. p. 1

ESSOP, P. 2005. Cape farms start to run out of water. The Cape Argus. Jan. [WEB:] http://www. agriafrica.biz/archived.html. [Date of access:] 15 February 2005. 
FAULKNER, B.\& VIKULOV, S. 2001. Washed out one day, back on track the next: a post-mortem of a tourism disaster. Tourism Management, 22:331-344.

FOURIE, C. 1998. "Den goeden ouden tijd”. The Mossel Bay Advertiser. 1, 1 May.

GELDENHUYS, H. 2005. Interview with author. Plettenberg Bay.

GUELKE, L. \& SHELL, R. 1992. Landscape of conquest: frontier water alienation and Khoikhoi strategies of survival, 1652-1780. Journal of Southern African Studies, 18(4), Des. p. 816.

GUNN, S.W.A. 1992. The scientific basis of disaster management. Disaster Prevention and Management, 1(3): p. 17.

HEALTH SYSTEMS TRUST. 2003. Decentralising Health Services in South Africa: Constraints and Opportunities.

HEALTH DEPARTMENT, GEORGE MUNICIPALITY. 2000. File 17/1/3/6 vol 2: Gesondheid: aansteeklike en oordraagbare siektes. 13 Aug.

IISD. 2005. Climate and Atmosphere. [WEB:] http://www.iisd.ca/recent/recentme etings.asp?id=5. [Date of access:] 15 February 2005.

JEGGLE, T in ROSENTHAL. U., COMFORT, L. AND BOIN, A. 2001. Managing Crisis: A Global Perspective. C.C. Thomas Publishers. Pp. 334-335.

JONES, D. 2005. End of line for Choo-Tjoe. Knysna-Plette Herald. p. 4.

JOUBERT, P. 2005. Interview with author. Knysna.

KNOETZEN, J. 2005. Interview with author. George.

LANGLANDS, S. 2005. Interview with author. Knysna.

LEGGAT, P. A. \& KLEIN, M. 2001. Personal safety advice for travellers abroad. The Journal for Travel Med, 8:46-51.

LIEBENBERG, N. 2005. Interview with author. Mossel Bay.

LIEBENBERG, N. 2005. Interview with author. Hartenbos.

LOMBAARD, P. 2005. Interview with author. Plettenberg Bay.

MACKAY, M. 1996. The Knysna elephants and their forest home. Wildlife and Environment Society of South Africa: Knysna centre, Knysna. Pp. 27.

MALAN. G.F. 1970. Die brullende leeu getem: die geskiedenis van die mense en die ontwikkeling van die besproeiingsboerdery in die Gamtoosvallei, (N.p. Patensie, 1970), p. 12; Millwood House Museum Archive, Knysna. 1954/1457;

MDINGI, C. 2005. Interview with author. George.

MEYER, I. 1999. Prince Alfred's Pass: spectacular and divers. Bowles: Oudtshoorn. Pp. 16-17.

NELSON, B. 2005. Interview with author. George.

OTTO, G. 2005. Interview with author. George.

PARKES, M. \& WILLIAMS, V. 2004. George Rex of Knysna: a trail. EMU. Knysna. Pp. 3-5.

PAULSEN, D. 2004. Early Warning and forecasting: advanced certificate course in disaster studies. African Centre for Disaster Studies. North-West University, Potchefstroom. 
Johan Tempelhoff et al.

PIETERS, J. 2005. Interview with author. Knysna.

PRETORIUS, A. P. 2005. Interview with author. Knysna.

RAPER. P.E. 2004. New Dictionary of South African Place Names. Jonathan Ball Publishers: Johannesburg and Cape Town. 2ed. Pp 421.

ROSENTHAL, U., COMFORT, L \& BOIN, A. 2001. Managing Crisis: A Global Perspective. C.C. Thomas Publishers. Pp335.

SANTANA, G. 2003. Crisis management and tourism: beyond the rhetoric. Journal of Travel \& Tourism Marketing, 4: 299.

SAYERS, C.C. 1982. Looking back on George: a medley of musings and memories. Herald Phoenix: George. Pp. 20.

SCHOLTZ, A. 2005. Popular Garden Route train 'derailed' by flood damage. The Eastern Province Herald. 1, 14 Jan.

SCHULZE, R.E. 2005. Climate Change and Water Resources in Southern Africa: Studies on Scenarios, Impacts, Vulnerabilities and Adaptation. Water Research Commission, Pretoria, RSA, WRC Report 1430/1/05. Chapter 4, Pp. 57-74.

SLEIGH, D. 2004. Die buiteposte: VOC-buiteposte onder Kaapse bestuur 1652-1795. Protea Boekhuis: Pretoria. Pp. 616.

SPARRMAN, A. 1975. A voyage to the Cape of Good Hope, towards the Antarctic polar circle, round the world and to the country of the Hottentots and the caffres from the year 1772-1776. Volume I, (Edited by VS Forbes. Translation from the Swedish revised by J and I Rudner, Van Riebeeck Society, Second series No. 6, Cape Town, 1975). Pp. 217.

STALS, E.L.P. 1961. George: the story of the town and district. Pro Ecclesia: Stellenbosch Printers. Pp. 74-82.

STATISTICS SOUTH AFRICA. 2001. Census figures 2001: Western Cape. [WEB:] http://www. answers.com/topic/western-cape-province. [Date of access:] 1 April 2005.

SOUTH AFRICAN WEATHER SERVICE. 2005. Pretoria. April.

SOUTH AFRICA. 1996. The Constitution of South Africa Act, no 108 of 1996. Pretoria: Government Printer.

SOUTH AFRICA. 1998. The National Water Act, no 36 of 1998. Pretoria: Government Printer.

SOUTH AFRICA. 1999. White Paper on Disaster Management. Pretoria: Government Printer.

SOUTH AFRICA. 2003. Disaster Management Act, no 57 of 2003. Pretoria: Government Printer.

SOUTH AFRICA. 2004. Department of Water Affairs and Forestry: Internal Strategic Perspective: Gouritz Water Management Area. Version, March:pi.

SWANEPOEL. J. 2005. Interview with author. George.

SWIEGERS, G. 2005. Interview with author. Plettenberg Bay.

VAN DER MERWE, I. 2002. The Knysna and Tsitsikamma forests: their history, ecology and management. Directorate Forestry of the Department of Water Affairs and Forestry. Tafel berg Publishers. 2ed. Pp 28.

VAN DER WALDT, A.J.H., WIID, J.A., GEYER, A.L., KRüGER, D.W. 1955 .Geskiedenis van SuidAfrika. Nasou Beperk: Goodwood. 2ed. Pp 660. 
VAN NIEKERK, D. 2001. Intersectoral model for disaster contingency planning. TSA, MPM.

VAN NIEKERK, D. 2004. Disaster reduction and sustainable development. Keynote address at the First Convocation of the Heads and Directors of Disaster Management Organisations, Abuja, Nigeria, 5-7 July 2004.

VAN NIEKERK, D. 2005. Confidential information. 12 May.

VAN RENSBURG, P. 2005. Interview with author. Mossel Bay.

WILLIAMS, L. 2005. Disasters on the increase? Business Day. [WEB:] http://transcripts.businessday. co.za/cgi-bin/transcripts/t showtranscript.pl?1105749088. [Date of access:] 1 April 2005.

\section{Notes}

I. The research team, after discussions with officials at various local authorities, concluded that it would be acceptable to come to this conclusion, particularly for the months of December and the early part of January every year.

II. See section 51 of the Disaster Management Act. 